\title{
Infiltrating Renal Pelvis Urothelial Carcinoma, Sarcomatoid Variant
}

National Cancer Institute

\section{Source}

National Cancer Institute. Infiltrating Renal Pelvis Urothelial Carcinoma, Sarcomatoid

Variant. NCI Thesaurus. Code C6186.

An infiltrating transitional cell carcinoma that arises from the renal pelvis and exhibits sarcomatoid features. 